\title{
PENINGKATAN PENDOKUMENTASIAN CATATAN PERKEMBANGAN PASIEN TERINTEGRASI MELALUI PENGUATAN PERAN KEPALA RUANG DENGAN PENDEKATAN TEORI ORLANDO
}

\author{
Dwi Nopriyanto1, Rr. Tutik Sri Hariyati ${ }^{2}$, Titin Ungsianik ${ }^{3}$
}

\author{
1Program Studi DIII Keperawatan Fakultas Kedokteran Universitas Mulawarman, Kalimantan Timur. \\ Email: d.nopriyanto@yahoo.co.id \\ 2Departeman Dasar Keperawatan Dasar, Fakultas IImu Keperawatan Universitas Indonesia \\ 3Departemen Keperawatan Maternitas Fakultas IImu Keperawatan Universitas Indonesia
}

\section{ABSTRACT: PUTTING ORLANDO'S THEORY INTO PRACTICE: APPROACH TO INTEGRATED DEVELOPMENT}

Background: Documentation of integrated patient development records has not been optimal due to lack of understanding of nurse in writing, and uniformity of the content of writing rules, and there has not yet optimal support from the head nurse.

Purpose: This study is to identify the impact of strengthening the role of the head nurse using the Orlando's theory approach on the implementation in documented of integrated patient development records.

Methods: Pre experimental design with one group pre test and post test design without control, samples on this study are 115 documents of integrated patient development record, cluster sampling technique, analyzed used with Wilcoxon, Spearman and Kruskal Wallis test analysis.

Results: Showing that the role strengthening of the head nurse with the Orlando's theory approach significantly improves the quality of implementation for documented of integrated patient development record $(p=0.0001$; $a=0,025)$. Conclusion: The nursing abilities of the implementers increased significantly in the implementation in documented of integrated patient development record.

Recommendation: As reference to make policies, assistance, evaluation and monitoring of nursing managers and development through workshops on the role of the head nurse and implementation documentation of integrated patient development records.

\section{Keywords: Integrated patient development records, role of the head nurse, Orlando's theory}

Pendahuluan: Dokumentasi catatan perkembangan pasien terintegrasi belum optimal karena kurangnya pemahaman perawat dalam melakukan penulisan, dan keseragaman dari isi kaidah penulisan, serta belum optimalnya dukungan dari kepala ruang.

Tujuan: Mengidentifikasi pengaruh penguatan peran kepala ruang dengan pendekatan Teori Orlando terhadap pelaksanaan pendokumentasian catatan perkembangan pasien terintegrasi.

Metode: Pre eksperiment design dengan one group pre test and post test design without control, dengan sampel 115 dokumen catatan perkembangan pasien terintegrasi, teknik cluster sampling, melalui analisis Wilcoxon, Spearman dan Kruskal Wallis test.

Hasil: Penguatan peran kepala ruang dengan pendekatan Teori Orlando meningkatkan kualitas pelaksanaan pendokumentasian catatan perkembangan pasien terintegrasi secara bermakna $(p=0,0001 ; \alpha=0,025)$.

Simpulan: Kemampuan perawat pelaksana meningkat bermakna dalam pelaksanaan pendokumentasian catatan perkembangan pasien terintegrasi melalui penguatan peran kepala ruang dengan pendekatan Teori Orlando.

Rekomendasi: Perlunya kebijakan, pendampingan, evaluasi, dan monitoring dari manajer keperawatan serta pengembangan melalui workshop penerapan peran kepala ruang dan pelaksanaan pendokumentasian catatan perkembangan pasien terintegrasi.

Kata kunci: Catatan perkembangan pasien terintegrasi, peran kepala ruang, Teori Orlando 
PENINGKATAN PENDOKUMENTASIAN CATATAN PERKEMBANGAN PASIEN TERINTEGRASI MELALUI PENGUATAN PERAN KEPALA RUANG DENGAN PENDEKATAN TEORI ORLANDO

\section{PENDAHULUAN}

Dokumentasi keperawatan merupakan proses yang penting dari praktik keperawatan dalam setiap intervensi keperawatan, berkontribusi dalam kesehatan pasien, memfasilitasi komunikasi antar perawat dan anggota kelompok pemberi layanan kesehatan lainnya (Ioanna, Stiliani, \& Vasiliki, 2007; John \& Bhattacharya, 2016). Mutu dan akurasi dokumentasi meningkatkan efisiensi, dan profesionalisme sesuai dengan standar pelayanan (Blair \& Barbara Smith, 2012; John \& Bhattacharya, 2016).Perawat manajer memiliki peran mendidik, memotivasi perawat untuk mengembangkan keterampilan dalam melaksanakan dokumentasi keperawatan (Nakate, Dahl, Petrucka, Drake, \& Dunlap, 2015; Taylor, 2003). Witges \& Scanlan, (2014) Kepemimpinan dan keterampilan yang ditunjukkan oleh seorang manajer langsung berdampak pada kinerja perawat dalam melaksanakan asuhan, berpengaruh pada hasil outcame pasien.

Teori Orlando menjelaskan interaksi perawatpasien melibatkan timbal balik, membuat hubungan yang dinamis dan kolaboratif. Perawat mengkonfirmasi persepsi, pikiran dan/ atau perasaan dengan pasien untuk validasi sebelum memilih kegiatan (Sheldon \& Ellington, 2008). Laurent, (2000) mengatakan model teori Orlando menjelaskan hubungan dinamis antara perawat dan pasien serta melibatkan validasi bersamasama antara pemimpin dan perawat pelaksana. Seorang pemimpin memberikan arahan kepada perawat pelaksana akan memungkinkan terjadinya partisipasi yang maksimal dari hubungan yang dinamis.

Adanya umpan balik, membuat hubungan yang dinamis dan berkoloborasi merupan bagian dari peran kepala ruang, menjadi panduan dalam bagaimana mengaitkan konsep The Dynamic Nurses-Patient Relationship teori Orlando dalam peran kepala ruang. Kedekatan dalam proses pengajaran antara atasan dan pelaksana sebagai hal yang tepat untuk menigkatkan perilaku (Darawad \& Al-Hussami, 2013). Penguatan keterampilan peran kepala ruang terhadap pelaksanaan asuhan dengan pendekatan teori Ida Jean Orlando berpengaruh terhadap pelaksanaan pendokumentasian catatan pekembangan pasien terintegrasi.
Studi pendahuluan yang dilakukan di rumah sakit $X$ didapatkan dari 15 dokumentasi CPPT di empat ruang rawat sekitar 3 dokumen memiliki nilai (62,5), 7 dokumen memiliki nilai (75) dan 5 dokumen memilki nilai $(87,5)$. Belum optimalnya pendokumentasian karena kurangnya pemahaman perawat dalam melakukan penulisan dan belum adanya keseragaman dari isi kaidah penulisan, serta belum optimalnya dukungan dari kepala ruang.

\section{METODE PENELITIAN}

Desain penelitian ini menggunakan pendekatan pre eksperiment design dengan one group pre test and post test design without control dimana pada desain ini peneliti hanya melakukan intervensi pada satu kelompok tanpa perbandingan, yang melihat pengaruh suatu intervensi, yaitu penguatan peran kepala ruang dengan pendekatan teori Orlando terhadap pelaksanaan pendokumentasian catatan perkembangan pasien terintegrasi. Populasi dalam penelitian ini adalah dokumen pendokumentasian catatan perkembangan pasien terintegrasidi Rumah Sakit $X$ saat dilakukan penelitian.

$\mathrm{N}$ sampel yang didapatkan sebanyak 115 dokumen dengan teknik cluster sampling, dengan menetapkan sampel pada tiap cluster dengan analisis Wilcoxon. Total seluruh waktu penelitian mulai dari penyusunan proposal hingga sidang kurang lebih 6 bulan dimulai awal Pebruari sampai awal Juli 2017. Intervensi dilakukan mulai dari pre test pengambilan dokumen secara restrospektif, mengobservasi peran kepala ruang, memberi penguatan peran kepala ruang, menobservasi kembali peran kepala ruang setelah penguatan, kemudian terakhir melakukan post test dengan mengobservasi pendokumentasian di ruang rawat yang telah ditetapkan.

Dwi Nopriyanto' Program Studi DIll Keperawatan Fakultas Kedokteran Universitas Mulawarman, Kalimantan Timur. Email: d.nopriyanto@yahoo.co.id

Rr. Tutik Sri Hariyati ${ }^{2}$ Departeman Dasar Keperawatan Dasar, Fakultas llmu Keperawatan Universitas Indonesia Titin Ungsianik ${ }^{3}$ Departemen Keperawatan Maternitas Fakultas Ilmu Keperawatan Universitas Indonesia 
PENINGKATAN PENDOKUMENTASIAN CATATAN PERKEMBANGAN PASIEN TERINTEGRASI MELALUI PENGUATAN PERAN KEPALA RUANG DENGAN PENDEKATAN TEORI ORLANDO

\section{HASIL}

Tabel 1. Perbedaan kompetensi kepala ruang menggunakan pendekatan teori Orlando April- Mei 2017 $(\mathrm{N}=15)$

\begin{tabular}{|c|c|c|c|c|c|c|}
\hline \multicolumn{2}{|l|}{ Peran Kepala Ruang } & \multirow{2}{*}{$\begin{array}{l}\text { Mean } \\
3,80 \\
\end{array}$} & \multirow{2}{*}{$\begin{array}{l}\begin{array}{l}\text { Mean } \\
\text { Differences }\end{array} \\
2,600\end{array}$} & \multirow{2}{*}{$\begin{array}{l}\text { Standar } \\
\text { Deviasi } \\
0,561 \\
\end{array}$} & \multirow{2}{*}{$\begin{array}{l}95 \% \mathrm{Cl} \\
2,14-3,059\end{array}$} & \multirow{2}{*}{$\begin{array}{l}p \\
0,0005^{*}\end{array}$} \\
\hline $\begin{array}{ll}\text { Fungsi } & \text { keperawatan }\end{array}$ & Sebelum & & & & & \\
\hline $\begin{array}{l}\text { profesional dan mengenal } \\
\text { perilaku (Peran hubungan } \\
\text { antar pribadi/ Interpersonal) }\end{array}$ & Sesudah & 6,40 & & 0,632 & & \\
\hline \multirow[t]{2}{*}{ - Figurehead/ Tokoh } & Sebelum & 1,87 & \multirow[t]{2}{*}{0,067} & 0,35 & $0,187-0,320$ & \multirow[t]{2}{*}{0,282} \\
\hline & Sesudah & 1,93 & & 0,26 & & \\
\hline \multirow[t]{2}{*}{ - Leader/pemimpin } & Sebelum & 0,27 & \multirow[t]{2}{*}{2,333} & 0,46 & $1,932-2,734$ & \multirow[t]{2}{*}{$0,0005^{*}$} \\
\hline & Sesudah & 2,60 & & 0,51 & & \\
\hline \multirow[t]{2}{*}{ - Laison/penghubung } & Sebelum & 1,67 & \multirow[t]{2}{*}{0,200} & 0,49 & $0,029-0,429$ & \multirow[t]{2}{*}{0,042} \\
\hline & Sesudah & 1,87 & & 0,35 & & \\
\hline \multirow{2}{*}{$\begin{array}{l}\text { Kesegeraan/respon internal } \\
\text { (Peran pemberi informasi/ } \\
\text { Informational) }\end{array}$} & Sebelum & 1,40 & \multirow[t]{2}{*}{3,267} & 0,828 & $2,824-3,709$ & \multirow[t]{2}{*}{$0,0005^{*}$} \\
\hline & Sesudah & 4,67 & & 0,617 & & \\
\hline \multirow[t]{2}{*}{ - Monitor } & Sebelum & 0,87 & \multirow[t]{2}{*}{1,133} & 0,35 & $0,938-1,328$ & \multirow[t]{2}{*}{$0,0001^{*}$} \\
\hline & Sesudah & 2,00 & & 0,00 & & \\
\hline \multirow[t]{2}{*}{ - Dissemenator/penyebar } & Sebelum & 0,40 & \multirow[t]{2}{*}{1,266} & 0,63 & $0,937-1,595$ & \multirow[t]{2}{*}{$0,0001^{*}$} \\
\hline & Sesudah & 1,67 & & 0,49 & & \\
\hline \multirow[t]{2}{*}{ - Spokesman/Juru bicara } & Sebelum & 0,13 & \multirow[t]{2}{*}{1,600} & 0,75 & $0,455-1,278$ & \multirow[t]{2}{*}{$0,002^{*}$} \\
\hline & Sesudah & 1,00 & & 0,36 & & \\
\hline \multirow{2}{*}{$\begin{array}{l}\text { Disiplin proses } \\
\text { dan improverawatan } \\
\text { pengambil (Peran } \\
\text { Decisional) }\end{array}$} & Sebelum & 3,80 & \multirow[t]{2}{*}{2,400} & 0,676 & $1,992-2,808$ & \multirow[t]{2}{*}{$0,0001^{*}$} \\
\hline & Sesudah & 6,20 & & 0,676 & & \\
\hline \multirow{2}{*}{ - Entrepreneur } & Sebelum & 1,00 & \multirow[t]{2}{*}{0,00} & 0,00 & & 0,500 \\
\hline & Sesudah & 1,00 & & 0,00 & & \\
\hline - Destrubance/ pengendali & Sebelum & 0,27 & 1,600 & 0,45 & $1,319-1,880$ & $0,0001^{*}$ \\
\hline gangguan & sesudah & 1,87 & & 0,35 & & \\
\hline - Resource Allocator/ & Sebelum & 1,67 & 0,066 & 0,49 & $0,076-0,295$ & 0,159 \\
\hline Pengelola sumberdaya & Sesudah & 1,73 & & 0,46 & & \\
\hline - Negotiator/ Negosiasi & Sebelum & 0,87 & 0,733 & 0,35 & $0,404-1,062$ & $0,001^{*}$ \\
\hline & Sesudah & 1,60 & & 0,51 & & \\
\hline
\end{tabular}

\section{*Signifikan One tailed $\alpha<0,025$}

Tabel 1 menunjukkan hasil analisis membuktika bahwa ada peningkatan yang signifikan kompetensi kepala ruang dengan pendekatan teori Orlando pada peran hubungan antar pribadi rerata nilai 2,600 ( $p=0,0005$; $a=0,025)$, peran pemberi informasi rerata nilai $3,267(p=0,0005 ; a=0,025)$, peran pengambil keputusan rerata nilai $2,400 \quad(\quad p=0,0001 ; \quad \alpha=0,025) \quad$ sebelum dan sesudah penguatan.

\section{Tabel 2. Pelaksanaan pendokumentasian catatan perkembangan pasien terintegrasi pada penguatan peran kepala ruang dengan teori Orlando April-Mei 2017}

Dwi Nopriyanto' Program Studi DIll Keperawatan Fakultas Kedokteran Universitas Mulawarman, Kalimantan Timur.

Email: d.nopriyanto@yahoo.co.id

Rr. Tutik Sri Hariyati ${ }^{2}$ Departeman Dasar Keperawatan Dasar, Fakultas Ilmu Keperawatan Universitas Indonesia

Titin Ungsianik ${ }^{3}$ Departemen Keperawatan Maternitas Fakultas Ilmu Keperawatan Universitas Indonesia 
PENINGKATAN PENDOKUMENTASIAN CATATAN PERKEMBANGAN PASIEN TERINTEGRASI MELALUI PENGUATAN PERAN KEPALA RUANG DENGAN PENDEKATAN TEORI ORLANDO

\begin{tabular}{|c|c|c|c|c|c|c|c|}
\hline $\begin{array}{c}\text { Pelaksanaan } \\
\text { Pendokumentasian } \\
\text { CPPT }\end{array}$ & & $\mathrm{n}$ & Mean & $\begin{array}{c}\text { Mean } \\
\text { Defference }\end{array}$ & $\begin{array}{l}\text { Standar } \\
\text { Deviasi }\end{array}$ & $\mathrm{Cl} 95 \%$ & $p$ \\
\hline \multirow{2}{*}{$\begin{array}{l}\text { Pelaksanaan } \\
\text { pendokumentasian }\end{array}$} & Sebelum & 115 & 26,43 & \multirow[t]{2}{*}{5,809} & 1,352 & \multirow[t]{2}{*}{$5,480-6,138$} & \multirow[t]{2}{*}{$0,0001^{*}$} \\
\hline & Sesudah & & 32,24 & & 1,213 & & \\
\hline \multirow[t]{2}{*}{ Legal Aspek } & Sebelum & 115 & 8,99 & \multirow[t]{2}{*}{0,0001} & 0,093 & \multirow[t]{2}{*}{$-0,24-0,24$} & \multirow[t]{2}{*}{0,500} \\
\hline & Sesudah & & 8,99 & & 0,093 & & \\
\hline \multirow[t]{2}{*}{ Kelengkapan } & Sebelum & 115 & 7,40 & \multirow[t]{2}{*}{1,957} & 0,673 & \multirow[t]{2}{*}{$1,751-2,165$} & \multirow[t]{2}{*}{$0,0001^{*}$} \\
\hline & Sesudah & & 9,36 & & 0,850 & & \\
\hline \multirow[t]{2}{*}{ Kesinambungan } & Sebelum & 115 & 10,04 & \multirow[t]{2}{*}{3,861} & 1,280 & \multirow[t]{2}{*}{$3,608-4,114$} & \multirow[t]{2}{*}{$0,0001^{x}$} \\
\hline & Sesudah & & 13,90 & & 0,675 & & \\
\hline
\end{tabular}

\section{*Signifikan one tailed pada $a<0,025$}

Tabel 3. Hubungan Karateristik Perawart (umur dan masa kerja) dengan Pelaksanaan Pendokumentasian Catatan Perkembangan Pasien Terintegrasi April-Mei 2017 (N=60)

\begin{tabular}{llccc}
\hline \multicolumn{1}{c}{ Variabel } & $\begin{array}{c}\text { Pelaksanaan } \\
\text { Pendokumentasian } \\
\text { CPPT }\end{array}$ & $\mathbf{R}$ & $\mathbf{R}^{2}$ & $\mathbf{P}$ \\
\hline Usia & Pelaksanaan & 0,002 & 0,0001 & 0,362 \\
\hline Masa Kerja & Pendokumentasian & 0,034 & 0,001 & 0,241 \\
\hline Usia & Legal Aspek & 0,057 & 0,003 & 0,489 \\
\hline Masa Kerja & 0,151 & 0,023 & 0,121 \\
\hline Usia & Kelengkapan & 0,126 & 0,016 & 0,221 \\
\hline Masa Kerja & 0,083 & 0,007 & 0,302 \\
\hline Usia & Kesinambungan & 0,134 & 0,018 & 0,070 \\
\hline Masa Kerja & 0,103 & 0,011 & 0,117 \\
\hline
\end{tabular}

*Signifikan one tailed $\alpha<0,05$

Tabel 2 secara analisis membuktikan ada peningkatan signifikan pada pendokumentasian catatan perkembangan pasien terintegrasi sesudah penguatan peran kepala ruang dengan pendekatan teori Orlando sebesar rerata nilai $5,809(p=0,0001 ; \alpha=0,025)$. Pada aspek kelengkapan rerata nilai $1,957(p=0,0001 ; \alpha=0,025)$, dan kesinambungan rerata nilai $3,861(p=0,0001 ; \alpha=0,025)$.

Pada tabel 3 secara uji statistik hubungan positif tetapi tidak ada hubungan yang signifikan antara pelaksanaan pendokumentasian catatan perkembangan pasien terintegrasi dengan umur dan masa kerja, baik pada legal aspek, aspek kelengkapan, dan kesinambungan $(p>0,05)$.

Tabel 4. Perbedaan Karakteristik (jenis kelamin, pendidikan dan status kepegawaian) dengan Pelaksanaan Pendokumentasian Catatan Perkembangan Pasien Terintegrasi di Rumah Sakit X April-Mei $2017(\mathrm{~N}=60)$

Dwi Nopriyanto' Program Studi Dlll Keperawatan Fakultas Kedokteran Universitas Mulawarman, Kalimantan Timur. Email: d.nopriyanto@yahoo.co.id

Rr. Tutik Sri Hariyati ${ }^{2}$ Departeman Dasar Keperawatan Dasar, Fakultas llmu Keperawatan Universitas Indonesia Titin Ungsianik ${ }^{3}$ Departemen Keperawatan Maternitas Fakultas Ilmu Keperawatan Universitas Indonesia 
PENINGKATAN PENDOKUMENTASIAN CATATAN PERKEMBANGAN PASIEN TERINTEGRASI MELALUI PENGUATAN PERAN KEPALA RUANG DENGAN PENDEKATAN TEORI ORLANDO

\begin{tabular}{|c|c|c|c|c|c|}
\hline \multirow[t]{2}{*}{ Variabel Independen } & \multirow{2}{*}{$\begin{array}{l}\text { Pelaksanaan } \\
\text { Pendokumentasian } \\
\text { CPPT }\end{array}$} & \multicolumn{4}{|c|}{ Pelaksanaan Pendokumentasian CPPT } \\
\hline & & $\mathrm{n}$ & Rata-rata & SD & $p$ \\
\hline \multicolumn{6}{|c|}{ Jenis Kelamin } \\
\hline Laki-laki & \multirow{2}{*}{$\begin{array}{l}\text { Pelaksanaan } \\
\text { pendokumentasian }\end{array}$} & 16 & 32,06 & 1,063 & \multirow{2}{*}{0,285} \\
\hline Perempuan & & 44 & 32,23 & 1,118 & \\
\hline Laki-laki & \multirow{2}{*}{ Legal Aspek } & 16 & 9,00 & 0,001 & \multirow{2}{*}{0,273} \\
\hline Perempuan & & 44 & 8,98 & 0,151 & \\
\hline Laki-laki & \multirow{2}{*}{ Kelengkapan } & 16 & 9,13 & 0,619 & \multirow{2}{*}{0,144} \\
\hline Perempuan & & 44 & 9,36 & 0,750 & \\
\hline Laki-laki & \multirow{2}{*}{ Kesinambungan } & 16 & 13,94 & 0,854 & \multirow{2}{*}{0,375} \\
\hline Perempuan & & 44 & 13,89 & 0,722 & \\
\hline \multicolumn{6}{|c|}{ Pendidikan } \\
\hline Diploma & \multirow{3}{*}{$\begin{array}{l}\text { - Pelaksanaan } \\
\text { - Pendokumentasia }\end{array}$} & 55 & 32,18 & 1,090 & \multirow{3}{*}{0,411} \\
\hline Sarjana Keperawatan & & 1 & 32,00 & - & \\
\hline Ners & & 4 & 32,25 & 0,750 & \\
\hline Diploma & \multirow{3}{*}{ Legal Aspek } & 55 & 8,98 & 0,135 & \multirow{3}{*}{0,478} \\
\hline Sarjana Keperawatan & & 1 & 9,00 & - & \\
\hline Ners & & 4 & 9,00 & 0,001 & \\
\hline Diploma & \multirow{3}{*}{ Kelengkapan } & 55 & 9,29 & 0,737 & \multirow{3}{*}{0,354} \\
\hline Sarjana Keperawatan & & 1 & 9.00 & - & \\
\hline Ners & & 4 & 9,50 & 0,577 & \\
\hline Diploma & \multirow{3}{*}{ Kesinambungan } & 55 & 13,91 & 0,727 & \multirow{3}{*}{0,498} \\
\hline Sarjana Keperawatan & & 1 & 14,00 & - & \\
\hline Ners & & 4 & 13,75 & 1,258 & \\
\hline \multicolumn{6}{|c|}{$\begin{array}{ll}\text { Status Kepegawaian } \\
\end{array}$} \\
\hline Non PNS & \multirow{2}{*}{$\begin{array}{l}\text { Pelaksanaan } \\
\text { Pendokumentasia }\end{array}$} & 48 & 32,17 & 1,018 & \multirow[b]{2}{*}{0,284} \\
\hline Pegawai Kontrak & & 12 & 32,25 & 1,422 & \\
\hline Non PNS & \multirow{2}{*}{ Legal Aspek } & 48 & 8,98 & 0,144 & \multirow{2}{*}{0,309} \\
\hline Pegawai Kontrak & & 12 & 9,00 & 0,001 & \\
\hline Non PNS & \multirow[b]{2}{*}{ Kelengkapan } & 48 & 9,31 & 0,689 & \multirow{2}{*}{0,367} \\
\hline Pegawai Kontrak & & 12 & 9,25 & 0,866 & \\
\hline Non PNS & \multirow[b]{2}{*}{ Kesinambungan } & 48 & 13,88 & 0,672 & \multirow[b]{2}{*}{0,236} \\
\hline Pegawai Kontrak & & 12 & 14,00 & 1,044 & \\
\hline
\end{tabular}

*Signifikan one tailed $\alpha<0,025$

Dwi Nopriyanto' Program Studi DIll Keperawatan Fakultas Kedokteran Universitas Mulawarman, Kalimantan Timur. Email: d.nopriyanto@yahoo.co.id

Rr. Tutik Sri Hariyati ${ }^{2}$ Departeman Dasar Keperawatan Dasar, Fakultas Ilmu Keperawatan Universitas Indonesia Titin Ungsianik ${ }^{3}$ Departemen Keperawatan Maternitas Fakultas Ilmu Keperawatan Universitas Indonesia 
PENINGKATAN PENDOKUMENTASIAN CATATAN PERKEMBANGAN PASIEN TERINTEGRASI MELALUI PENGUATAN PERAN KEPALA RUANG DENGAN PENDEKATAN TEORI ORLANDO

Tabel 4. menyampaikan tidak ada hubungan signifikan antara jenis kelamin dan status kepegawaian terhadap pelaksanaan pendokumentasian catatan perkembangan pasien terintegrasi $(p>0,025)$. Pada variabel pendidikan tidak ada hubungan signifikan dengan pelaksanaan pendokumentasian Catatan perkembangan pasien terintegrasi $(p>0,025)$, secara rerata nilai pelaksanaan pendokumentasian catatan perkembangan pasien terintegrasi perawat dengan pendidikan Ners lebih tinggi dari sarjana keperawatan dan pendidikan diploma dalam pelaksanaan pendokumentasian.

\section{PEMBAHASAN}

\section{Kompetensi Peran Kepala Ruang dengan Pendekatan Teori Orlando}

Peran kepala ruang sebagai manajer mengambil kerangka kerja dari teori Orlando yaitu The Dynamic Nurse-Patient Relationship: Function, Process and Principle of Professional Nursing Practice. Peran kepala ruang sebagai manajer diterapkan dalam melakukan hubungan dinamis antara kepala ruang sebagai manajer dan perawat pelaksana sebagai pemberi asuhan keperawatan kepada pasien. Laurent, (2000) mengusulkan model hubungan pemimpin yang dinamis. Hubungan yang dinamis antara kedua belah pihak sangat penting bagi keberhasilan unit. Laurent, (2000) mengatakan model Teori Orlando menjelaskan hubungan dinamis antara perawat dan pasien serta melibatkan validasi bersamasama antara pemimpin dan perawat pelaksana. Seorang pemimpin memberikan arahan kepada perawat pelaksana akan memungkinkan terjadinya partisipasi yang maksimal dari hubungan yang dinamis.

Valentine, (2005) berdasarkan Teori Orlando mengembangkan gagasan kepemimpinan keperawatan untuk perawat baru. Menjelaskan bahwa interaksi antara manajer dan perawat baru dapat mengembangkan prinsip kepemimpinan dasar melalui interaksi dengan pemimpin perawat yang telah mapan. Hasil analisis peneliti membuktikan bahwa peran kepala ruang sebagai manajer bagi perawat pelaksana akan mampu dilaksanakan maksimal serta dapat menciptakan hubungan yang dinamis dengan menggunakan pendekatan Teori Orlando antara kepala ruang dengan perawat pelaksana sebagai pemberi asuhan. Witges \& Scanlan, (2014) memperjelas bahwa kepemimpinan dan keterampilan yang ditunjukkan oleh seorang manajer langsung berdampak pada kinerja perawat dalam melaksanakan asuhan dan berpengaruh pada hasil outcame pasien.

\section{Fungsi keperawatan profesional dan mengenal perilaku dalam kompetensi peran hubungan antar pribadi.}

Sebagai seorang tokoh kepala ruang merupakan role model bagi perawat pelaksana. Kedekatan individu terhadap seorang pemimpin dipengaruhi faktor kesamaan antara suatu individu dengan lainnya seperti usia, etnik, sosial ekonomi, pendidikan, jenis kelamin (Jakson Dwyer \& Diana, 2014). Miri et al., (2014) menjelaskan bahwa kepala ruang juga harus berperan sebagai tokoh dimana kepala ruang berpartisifasi menyelesaikan masalah di unit kerja.

Peningkatan peran hubungan antar pribadi terutama pada peran sebagai seorang pemimpin sudah sangat baik tetapi belum optimal. Fakta mengatakan bahwa pemimpin yang baik berorentasi pada tujuan, memiliki inisiatif bersama (Suwandej, 2015). Gatling, Shum, Book, \& Bai (2017) menyimpulkan bahwa pemimpin yang baik harus konsisten dengan tujuan perbaikan produk dan layanan untuk kelangsungan hidup organisasi di sebuah lingkungan yang kompetitif. Lebih efektif, lebih baik memimpin individu di dalam organisasi akan berkontribusi untuk memberikan perbaikan sebaik mungkin penyediaan kesehatan (Chapman, Johnson, \& Kilner, 2014).

Peran sebagai penghubung meningkat pada peran hubungan antar pribadi, menjelaskan bahwa seorang kepala ruang harus mampu menjaga hubungan yang baik di dalam pelaksanaan asuhan. Kumar, (2015) menjelaskan bahwa seorang manajer berinteraksi dengan teman sebaya dan orang di luar organisasi. Almost et al., (2010); Kumah et al., (2016) manajer dituntut mempunyai hubungan yang baik dengan staf dan mampu menghadapi konflik serta mempunyai kompetensi penghubung antar staf dan pihak luar. Keterampilan kepala ruang menjalankan peran hubungan antar pribadi merupakan kompetensi yang harus diterapkan pada perawat. Agnew \&

Dwi Nopriyanto' Program Studi DIll Keperawatan Fakultas Kedokteran Universitas Mulawarman, Kalimantan Timur. Email: d.nopriyanto@yahoo.co.id

Rr. Tutik Sri Hariyati ${ }^{2}$ Departeman Dasar Keperawatan Dasar, Fakultas llmu Keperawatan Universitas Indonesia Titin Ungsianik ${ }^{3}$ Departemen Keperawatan Maternitas Fakultas Ilmu Keperawatan Universitas Indonesia 
PENINGKATAN PENDOKUMENTASIAN CATATAN PERKEMBANGAN PASIEN TERINTEGRASI MELALUI PENGUATAN PERAN KEPALA RUANG DENGAN PENDEKATAN TEORI ORLANDO

Flin, (2014) bahwa seorang pemimpin keperawatan harus memiliki kompetensi melakukan hubungan antar pribadi dengan perawat pelaksana untuk merubah perilaku perawat. Miri et al., (2014) mendukung penelitian diatas dengan mejelaskan bahwa kompetensi peran hubungan antar pribadi kepala ruang antara lain menjadi fasilitator pemecahan masalah, meningkatkan motivasi dan kepuasan kerja, melakukan supervisi berjenjang, memfasilitasi pengetahuan staf dan koloborasi antar departemen.

\section{Kesegeraan/respon internal dalam kompetensi peran pemberi informasi.}

Manajer keperawatan dapat menggunakan asumsi model kesegeraan dari teori Orlando, dimana reaksi segera mencakup gabungan bagaimana perawat mempersepsikan, ide dan perasaan perawat atas kebutuhan pasien secara situasional. Miri et al, (2014) menjelaskan peran monitor kepala ruang yaitu dengan mengontrol dan mengawasan pelaksanaan asuhan dengan melihat dokumentasi yang dilakukan oleh perawat, kepala ruang berperan sebagai penyebar informasi dimana bersama perawat perawat pelaksan merencanakan dan berkerjasama dalam pemberian laporan yang diperlukan dalam melaksanakan asuhan keperawatan. Peran pemberi informasi sebagai juru bicara, kepal ruang harus mampu menginformasikan semua hal yang berkaitan dengan pelayanan keatas serta berkoloborasi dengan bidang keperawatan dalam kebijakan rumah sakit.

Pelaksanaan peran kepala ruang sebagai pemberi informasi pada area manajemen, kepala ruang dapat diterapkan pada perawat pelaksana yang belum mengetahui kondisi budaya organisasi rumah sakit. Manajer keperawataan harus melakukan peran pemberi informasi baik didalam organisasi maupun di luar organisasi. informasi yang bermutu wajib diberikan oleh seorang manajer, membagikan informasi dan menjadi juru bicara di lingkungan dimana organisasi dipimpin oleh dirinya (Tappen, 2011). Manajer juga menyiapkan informasi untuk menjaga informasi yang disampaikan dan memberi kesempatan kepada perawat dalam mengambil keputusan (Skytt et al., 2008).

\section{Disiplin Proses Keperawatan dan Improvement dalam kompetensi peran pengambil keputusan.}

Kepala ruang sebagai pemimpin dituntut untuk kreatif dan penuh inovatif dalam mendapatkan peluang terkait dengan peningkatan mutu pelayanan, dimana seorang kepala ruang bertindak sebagai pengambil keputusan, dengan memprakasain rencana-rencana yang dapat membawa perubahan/kemajuan, mampu bertanggung jawab, mampu mengatasi masalah yang ada dengan cara menyetujui suatu keputusan yang dibuatnya (Robbins, \& Judge, 2013).

Peran sebagai entrepreneur menuntut seorang kepala ruang berperan sebagai perancang perubahan yang diharapkan untuk memperbaiki kinerja di dalam ruang rawat yang dipimpin oleh dirinya. Miri et al., (2014) bahwa sebagai seorang entrepreneur seorang manajer mampu meningkatkan kualitas pelayanan dan mengembangkan aturan diruang rawat untuk mencapai tujuan organisasi ruang rawat. Kumar, (2015) seorang manajer sebagai entrepreneur memiliki inisiatif dalam perubahan, mengidentifikasi gagasan baru dan mendelegasikan tanggung jawab ide kepada lainnya.

Kepala ruang dalam menjalankan peran sebagai pengambil keputusan harus mampu dalam menangani gangguan di ruang rawat. Seorang manajer harus mampu menangani ancaman dalam organisasinya, seorang manajer harus mengambil tindakan korektif selama terjadi perselisihan atau krisis serta menyelesaikan konflik yang terjadi antar bawahan (Kumar, 2015). Peran pengelola sumber daya, seorang kepala ruang memutuskan bagaimana menangani gangguan yang muncul dalam pekerjaan sehari-hari. Miri et al., (2014) dalam penelitiannya mengatakan peran pengambil keputusan seorang kepala ruang sebagai peran pengendali gangguan yaitu bagaimana kepala ruang mampu memantau atau mencegah terjadinya gangguan di ruang rawat. Sedangkan pada pengelolaan sumber daya bagaimana seorang pemimpin mampu mengelola dan mengalokasiakan sumberdaya yang ada.

Miri et al., (2014) mengatakan kepala ruang harus mampu menjalankan perannya sebagai negosiasi, bagaimana seorang kepala ruang sebagai seorang manajer harus mampu berkerjasama dan berpartisifasi dalam kegiatan.

Dwi Nopriyanto' Program Studi DIll Keperawatan Fakultas Kedokteran Universitas Mulawarman, Kalimantan Timur. Email: d.nopriyanto@yahoo.co.id

Rr. Tutik Sri Hariyati ${ }^{2}$ Departeman Dasar Keperawatan Dasar, Fakultas Ilmu Keperawatan Universitas Indonesia Titin Ungsianik ${ }^{3}$ Departemen Keperawatan Maternitas Fakultas Ilmu Keperawatan Universitas Indonesia 
PENINGKATAN PENDOKUMENTASIAN CATATAN PERKEMBANGAN PASIEN TERINTEGRASI MELALUI PENGUATAN PERAN KEPALA RUANG DENGAN PENDEKATAN TEORI ORLANDO

Peran perunding para kepala ruang berhubungan dengan dengan tawar-menawar yang representatif. Kepala ruang menjalankan peran pengambil keputusan dengan melibatkan sektor lain untuk mengatasi permasalahan yang tidak bisa diatasinya. Peran tersebut melibatkan atasan langsung, profesi lain atau mengikuti pertemua untuk menyelesaikan permasalahan tersebut. Perawat manajerial dan perawat pelaksana membutuhkan lebih banyak partisipasi dalam mengambil keputusan daripada mereka yang sudah terlatih (Ahmed \& Safadi, 2013)

\section{Implementasi pelaksanaan pendokumentasian catatan perkembangan pasien terintegrasi.}

Penelitian menunjukkan adanya peningkatan signifikan dari seluruh pelaksanaan pendokumentasian catatan perkembangan pasien terintegrasi baik dari legal aspek, kelengkapan maupun kesinambungan. Indikasi legal aspek dikaji dalam penelitian ini walapun tidak mengalami peningkatan, tetapi memiliki nilai pelaksanaan yang maksimal.

Potter \& Perry (2010) menjelaskan dalam pendokumentasian harus terdapat waktu, mencantumkan tanda tangan serta siapa yang terlibat dalam pelaksanaan. Perawat harus selalu menandatangani setiap notasi dalam catatan pasien seperti setelah melakukan tindakan pencatatan atau menerima perintah dokter (Lockwood, 2017). Cartwright-vanzant, (2010) menjelaskan bahwa mendokumentasikan dengan tepat waktu dan benar-benar untuk menghindari membuat catatan medis yang membingungkan, tidak akurat, atau tidak ada.

Pendokumentasian catatan perkembangan pasien terintegrasi pada penelitian ini kualitas pendokumentasian juga dilihat dari segi aspek kelengkapan data. Dokumentasi harus akurat, lengkap dan singkat, dimana dalam pencatatan setiap perubahan harus memiliki diskripsi yang benar dan jelas serta isi pendokumentasian harus konsisten tentang perkembangan pasien (Chelagat et al, 2013; Potter \& Perry, 2010). Sedangkan catatan perawatan yang tidak signifikan akan menjadi risiko kepada keselamatan pasien karena komunikasi yang tidak baik dari pemberi layanan, sehingga akan menunda pelayanan kepada pasien
(Griffiths, Anderson, Coyne, Beastall, \& Hill, 2011; Union in Health, 2012).

Kualitas dokumentasi keperawatan dilihat dari hasil pendokumentasian yang dilakukan oleh perawat, pendokumentasian yang dilakukan harus memiliki relevansi dan berkesinambungan dalam pelaksanaan pendokumentasian yang merupakan salah satu alat pengendali untuk dapat mengukur kualitas pelayanan keperawatan. Penelitian (Hariyati, Yani, Eryando, Hasibuan, \& Milanti, 2015) mengatakan efektif dan efisien untuk memperbaiki dokumentasi keperawatan dengan cara meningkatkan kualitas, kelengkapan dan keberlanjutan dan sistem pendukung keputusan. Chelagat et al., (2013) menjelaskan dalam penelitiannya dokumentasian keperawatan yang tepat memiliki berbagai prinsip termasuk objektivitas, konsistensi, komprehensif, menghargai kerahasiaan dan kesalahan rekaman. Karena dokumentasi keperawatan sangat penting dalam mengatur perawatan kesehatan dan mencerminkan berbagai aspek termasuk tingkat kesadaran perawat dalam perannya memberi layanan kesehatan dengan kualitas yang baik (Alkouri, Just, \& Kawafhah, 2016).

\section{SIMPULAN}

Kemampuan kompetensi peran kepala ruang baik peran hubungan antar pribadi, pemberi informasi, dan peran pengambil keputusan setelah mengikuti penguatan peran kepala ruang dengan pendekatan teori Orlando menggambarkan peningkatan, dimana peningkatan tertinggi terdapat pada peran pengambil keputusan.

Kemampuan perawat pelaksana meningkat bermakna dalam pelaksanaan pendokumentasian catatan perkembangan pasien terintegrasi setelah dilakukan penguatan peran kepala ruang dengan pendekatan teori Orlando. Begitu pula pada legal aspek, aspek kelengkapan dan kesimbungan.

Hasil penelitian menunjukkan tidak ada hubungan karateristik perawat (umur dan masa kerja) dengan pelaksanaan pendokumentasian catatan perkembangan pasien terintegrasi. Tidak ada perbedaan yang bermakna karateristik perawat (jenis kelamin, tingkat pendidikan dan status kepegawaian) dengan pelaksanaan pendokumentasia perkembangan pasien terintegrasi, tetapi secara rerata nila

Dwi Nopriyanto' Program Studi DIIl Keperawatan Fakultas Kedokteran Universitas Mulawarman, Kalimantan Timur.

Email: d.nopriyanto@yahoo.co.id

Rr. Tutik Sri Hariyati ${ }^{2}$ Departeman Dasar Keperawatan Dasar, Fakultas Ilmu Keperawatan Universitas Indonesia

Titin Ungsianik ${ }^{3}$ Departemen Keperawatan Maternitas Fakultas Ilmu Keperawatan Universitas Indonesia 
PENINGKATAN PENDOKUMENTASIAN CATATAN PERKEMBANGAN PASIEN TERINTEGRASI MELALUI PENGUATAN PERAN KEPALA RUANG DENGAN PENDEKATAN TEORI ORLANDO

pendokumentasian pendidikan Ners lebih tinggi dari sarjana keperawatan dan pendidikan diploma.

Meningkatnya kemampuan pelaksanaan pendokumentasian catatan perkembangan pasien terintegrasi perlu pendampingan dengan menggunakan lembar observasi pelaksanaan pendokumentasian sebagai proses pelaksanaan monitoring dan evaluasi secara berkesinambungan dari manajemen keperawatan. Serta adanya komitmen positif dari manajemen keperawatan untuk meningkatkan pengetahuan dan pendidikan perawat pelaksana ke jenjang Ners.

\section{UCAPAN TERIMA KASIH}

Puji syukur kepada Allah SWT, ucapan terima kasih ditujukan kepada orang tua tercinta, istri dan anak-anakku tercinta, pembimbing satu dan dua, penguji, rekan sejawat, penyandang dana beasiswa Pemerintah Provinsi Kalimantan Timur serta pihak lain yang telah memberikan dukungan.

\section{DAFTAR PUSTAKA}

Agnew, C., \& Flin, R. (2014). Senior charge nurses' leadership behaviours in relation to hospital ward safety: A mixed method study. International Journal of Nursing Studies, 51(5), 768-780.

http://doi.org/10.1016/j.jinurstu.2013.10.001

Ahmed, M. Z., \& Safadi, E. G. (2013). Decisional involvement among nurses: Governmental versus private hospitals. Health Science Journal, 7(1), 18-27.

Alkouri, O. A., Just, T., \& Kawafhah, M. (2016). Importance And Implementation Of Nursing Documentation: Review Study. European Scientific Journal, 12(3), 101-106. http://doi.org/10.19044/esj.2016.v12n3p101

Almost, J., Doran, D. M., Mcgillis Hall, L., \& Spence Laschinger, H. K. (2010). Antecedents and consequences of intra-group conflict among nurses. Journal of Nursing Management, 18(8), 981-992. http://doi.org/10.1111/j.1365$\underline{2834.2010 .01154 . x}$
Blair, W., \& Barbara Smith. (2012). Nursing Documentation: Framewor and barriers. Cotemporary Nurse, 41(2), 160-168.

Cartwright-vanzant, R. C. (2010). Medical record documentation: Legal aspects in neonatal nursing. Newborn and Infant Nursing Reviews, 10(3), 134-137. http://doi.org/10.1053/j.nainr.2010.06.008

Chelagat, D., Sum, T., Chebor, A., Kipto, R., \& Bundtich, P. (2013). Documentation: Historical perspectives, purposes, benefits and challenges as faced by nurses. International Journal of Humanities and Social Science, 3(16), 236-240. Retrieved from http://www.ijhssnet.com/journals/Vol_3_No_16 Special_Issue_August_2013/28.pdf

Chapman, A. L. N., Johnson, D., \& Kilner, K. (2014). Leadership styles used by senior medical leaders leadership development, 27(4), 283-298. http://doi.org/10.1108/LHS-03-2014$\underline{0022}$

Darawad, M. W., \& Al-Hussami, M. (2013). Jordanian nursing students' knowledge of, attitudes towards, and compliance with infection control precautions. Nurse Education Today, 33(6), 580-583. http://doi.org/10.1016/j.nedt.2012.06.009

Gatling, A., Shum, C., Book, L., \& Bai, B. (2017). International Journal of Hospitality Management The influence of hospitality leaders ' relational transparency on followers ' trust and deviance behaviors: Mediating role of behavioral integrity. International Journal of Hospitality Management, 62, 11-20. http://doi.org/10.1016/i.ijhm.2016.11.010

Griffiths, P., Anderson, A., Coyne, C., Beastall, H., \& Hill, J. (2011). Implementing an interprofessional patient record. Clinical Medicine, Journal of the Royal College of Physicians of London, 11(2), 128-131. http://doi.org/10.7861/clinmedicine.11-2-128

Dwi Nopriyanto' Program Studi DIII Keperawatan Fakultas Kedokteran Universitas Mulawarman, Kalimantan Timur. Email: d.nopriyanto@yahoo.co.id

Rr. Tutik Sri Hariyati ${ }^{2}$ Departeman Dasar Keperawatan Dasar, Fakultas Ilmu Keperawatan Universitas Indonesia Titin Ungsianik ${ }^{3}$ Departemen Keperawatan Maternitas Fakultas llmu Keperawatan Universitas Indonesia 
PENINGKATAN PENDOKUMENTASIAN CATATAN PERKEMBANGAN PASIEN TERINTEGRASI MELALUI PENGUATAN PERAN KEPALA RUANG DENGAN PENDEKATAN TEORI ORLANDO

Hariyati, S. T. R., Yani, A., Eryando, T., Hasibuan, Z., \& Milanti, A. (2015). The Effectiveness and Efficiency of Nursing Care Documentation Using the SIMPRO Model. International Journal of Nursing Knowledge, (January 2016). http://doi.org/10.1111/2047-3095.12086

Ioanna, P., Stiliani, K., \& Vasiliki, B. (2007). Nursing documentation and recording systems of nursing care. Healt Science Journal, (4).

Jakson Dwyer, \& Diana. (2014). Interpersonal relationships. New York: Routledge.http://doi.org/10.4324/9780203797853

John, S. K., \& Bhattacharya, P. C. (2016). Documentation guidelines based on expectation of documentation helps accurate documentation among nurses in psychiatric settings. Asian $\mathrm{J}$. Nursing Edu and Research, 6(June), 260-265. http://doi.org/10.5958/2349-2996.2016.00050.1

Kumah, E., Ankomah, S. E., \& Antwi, F. (2016). The Role of First-Line Managers in Healthcare Change Management: A Ghanaian Context Abstract: International Journal of BioSciences, Healthcare Technology and Management, 6(3), 20-33.

Kumar, P. (2015). An Analytical study on Mintzberg ' s Framework: Managerial Roles, 2(3).

Laurent, C. L. (2000). A nursing theory for nursing leadership. Journal of Nursing Management, 8(2), 83-87. $\quad$ http://doi.org/10.1046/j.1365$\underline{2834.2000 .00161 . x}$

Lockwood, W. (2017). Documentation : Accurate and Legal.

Miri, S. A., Mansor, N. N. A., Alkali, A., \& Chikaji, A. (2014). The role of first line nurse manager. Review of European Studies, 6(4), 31-41. http://doi.org/10.5539/res.v6n4p31

Nakate, G. M., Dahl, D., Petrucka, P., Drake, K. B., \& Dunlap, R. (2015). The Nursing Documentation Dilemma in Uganda: Neglected but Necessary. A Case Study at Mulago National Referral Hospital. Open Journal of Nursing, 5(December), 10631071. http://doi.org/10.4236/ojn.2015.512113
Potter, P.A., \& Perry, G.A. (2010). Fundamental of nursing (7th ed.). St. Louis: Mosbay Elsevier.

Robbins, P.S \& Judge, A. . (2013). Organizational Behavior (15th ed.). Boston: Pearson.

Sheldon, L. K., \& Ellington, L. (2008). Application of a model of social information processing to nursing theory: How nurses respond to patients. Compilation Journal of Advanced Nursing, 64(4), 388-398. http://doi.org/10.1111/j.13652648.2008.04795.x

Skytt, B., Ljunggren, B., Sjoden, P. O., \& Carlsson, M. (2008). The roles of the first-line nurse manager: Perceptions from four perspectives. Journal of Nursing Management, 16(8), 1012-1020. http://doi.org/10.1111/j.1365-2834.2006.00684.x

Suwandej, N. (2015). Factors Influencing Total Quality Management. Procedia - Social and Behavioral Sciences, 197(February), 2215-2222. http://doi.org/10.1016/i.sbspro.2015.07.361

Tappen, R. M. (2011). Advance nursing research: From theory to practice. USA: Joces \& Bartlett Learning.

Taylor, H. (2003). An exploration of the factors that affect nurses' record keeping. British Journal of Nursing, 12(12), 751-754-758.

Union in Health. (2012). Record Keeping Guidlines, (October).

Valentine, S. O. (2005). Nursing leadership and the new nurse. Journal of Undergraduate Nursing Scholarship, 4(1), 1. Retrieved May 18, 2005, from

http://juns.nursing.arizona.edu/articles/Fall\%2020 02/ Valentine.htm

Witges, K. A., \& Scanlan, J. M. (2014). Understanding the role of the nurse manager: The full-range leadership theory perspective. Nurse Leader, 12(6), 67-70.

Dwi Nopriyanto' Program Studi DIII Keperawatan Fakultas Kedokteran Universitas Mulawarman, Kalimantan Timur. 